\title{
Entrepreneurs Contextualisation of Culture in a National Setting
}

\begin{abstract}
Purpose: The purpose of this study is to capture the variation in entrepreneurs' understandings and experiences through which they contextualise cultural factors within a national setting to articulate how they use their knowledge and social capabilities to advance their activity.
\end{abstract}

Design/Methodology/Approach: this study adopts an interpretivist approach through which culture is investigated at the individual level. Phenomenography is used as a methodology to capture the variation in entrepreneurs' understanding and experiences of cultural factors.

Findings: The findings introduce four different understandings and eight experiences that enable us to explore how entrepreneurs contextualise culture in their environment. The findings present a change in the role of culture in influencing entrepreneurial social capabilities and confidence; and a change in the local culture from collectivism to individualism. Furthermore, the findings show how entrepreneurs use their knowledge, experience and understanding to achieve socially driven acts to pursue economic value, integration and acceptance.

Originality/value: In this study, phenomenography has enabled new insights into the multiplicity and idiosyncratic role of culture within a national setting and introduces a model of social capability and integration which capture the contextualisation of cultural factors. The study contributes to entrepreneurship literature as follows: first, the implicit assumption in this research is that culture is an active construct that entrepreneurs understand, experience and also influence; second, the variation in entrepreneurs' outcomes is based on their subjective and personal understandings which form the ways of contextualisation. Third, the variation in understanding and experiences captures the different ways entrepreneurs use their social capabilities to achieve integration and economic value.

Keywords: Entrepreneurship; Jordan; Phenomenography; contextualisation of culture

\section{Introduction:}

In entrepreneurship activity, culture plays a significant role in determining entrepreneurial intentions; and providing a social support for the entrepreneurial identity. In explaining the role of culture, research has emphasized entrepreneur's cognitive behaviour and responses to factors within their environment by explaining the dynamics (see Singh 2000). Therefore, most of these studies have examined culture as an external factor or as a backdrop to entrepreneurial activity to understand the 
influence of social acceptance and the role of the ecosystem in encouraging entrepreneurs and entrepreneurial activity (Garud; Gehman and Giuliani 2014; Welter, Baker and Wirsching 2018). The challenge in advancing the field of research has been attributed to rationalistic methodologies, through which researchers de-contextualise the role of culture to introduce generalisable results (Bamberger 2015; Klyver, Hindle and Meyer 2008). A shift in research approach is needed, to assess the influence of communities and culture on entrepreneurial intention formation as a causal process leading to behaviours (Linan, Urbano and Guerrero 2011; Vuorio, Puumalainen and Fellnhofer 2018). As Krueger states (2009, p. 53), “The construct of intentions appears to be deeply fundamental to human decision making and, as such, it should afford us multiple fruitful opportunities to explore the connection between intent and a vast array of other theories and models that relate to decision making". While Hoftstede (1980) explained the role of national culture and its effect on beliefs, attitudes and intentions relative to entrepreneurship, these influences are likely to be intermediated by stronger social relationships and networks. Therefore, to understand the role of culture as a context play a central role in the entrepreneurial actions. It is through actions contextualisation happens. Entrepreneurs are active individuals in their contexts, in the way they adapt, contribute to sustaining themselves and develop their activity (Herrera-Echeverri, Haar, Estevez-Breton 2013). It is through these interactions' entrepreneurs demonstrate and translate their cultural cognition which influences the desirability and feasibility of entrepreneurship (Fayolle and Linan 2014).

Therefore, to explore how entrepreneurs understand and experience culture as a context, an alternative philosophical approach is needed. In this study phenomenography, as an interpretive methodology, is used to capture the variation in the entrepreneurs' understanding and experiences. Through the interpretivist approach the research will present human intentionality as a key determinant of behaviour by investigating individuals' understandings, knowledge and experiences (Packard 2017). This shift in philosophical approach will present bottom-up behaviours, grounding higher-level phenomena to present complex forms of interactions and mechanisms in the cognitive world of the entrepreneur (Barandiaran et al. 2009; Brännback and Carsrud 2016). The shift in philosophical approach will provide an alternative lens that will allow a deeper understanding of culture through a deeper look into the individual meaning and purpose through which the contextualisation and interpretation of behaviours is articulated (Packard 2017). Therefore, the interpretive research tradition stipulates that what individuals do in relation to their activities and how they act are underpinned by how they understand factors within their environment (Sandberg 2005), in specific the cultural factors. Therefore, the human world is never a world, but rather it is an experienced world, which cannot be described without engagement and interactions (Husserl 1970); and human reality is socially constructed through on-going actions between individuals (Berger and Luckmann 1966; 1991). 
Therefore, the human action is based on their understanding of reality (Crotty 1998) and how people act is determined by their understanding of different aspects of their reality (Sandberg \& Targama 2007). Hence using an interpretive approach to capture how entrepreneurs contextualise cultural factors within their environment can provide a new lens through which to view their lived reality.

The purpose of this study is to capture the variation in entrepreneurs' understanding and experiences of cultural factors in their environment. The research question guiding this study is: "How do entrepreneurs understand and deal with cultural factors in their environment?" In explaining the role of culture, research has moved away from the previously dominant view, that culture can be categorised by country for purposes of international comparison (Klyver, Hindle and Meyer 2007); toward a view of culture as process or perspective - by focusing on culture as a dynamic multidimensional array of resources that enable or constrain action (Swidler 1986; Weber and Dacin 2011; Welter 2011). This new process-oriented approach to culture has introduced a new domain to culture by explicitly acknowledging "agency” (Lounsbury, Gehman and Glynn 2019). This research embraces the definition of culture as cited by Lounsbury and Glynn (2001, p. 549) as "a flexible set of tools that can be actively and strategically created and deployed as actors struggle to make sense of the world", focusing on the process of finding meaning by drawing on the resource capital to construct identity, legitimation and value creation (see Dalpiaz, Rindova and Ravasi 2016; Lounsbury and Glynn 2001). Moreover, researchers have highlighted the effects of entrepreneurial stories on their identity and legitimacy are shaped by market dynamics (see Zhao, Fisher, Lounsbury and Miller 2017). In this research, the focus is on entrepreneurial agency and how individuals contextualise cultural factors as tools and resources to achieve economic value. It is through entrepreneurs' actions we understand the mechanism employed as a process and the variation in their ability to understand and interpret the contexts their actions are taken, and decisions made (Lounsbury and Glynn 2001). It is through their ability to recognise the social processes and culture formation provided through contexts for resource allocation (Foss and Klein 2012). Indeed, entrepreneurs in Jordan deal with considerable cultural factors. Cultural values play a role in everyday life and every decision made, especially in relation to choices such as employment and risk taking (Alawamleh, Isamil; Aqeel and Alawahmleh, 2019). Literature on culture has largely reflected a US and Eurocentric bias (Al-Dajani and Marlow 2013). Taking this into consideration, this study will focus on entrepreneurs' understanding of culture in their local context in Jordan.

The role of entrepreneurship in developing economies have been criticized for its lack of making significant contribution to economic growth due to context (institutional and policy) and cultural factors (Sautet 2013; Naude 2010 and 2013). While research in developing economies have focused 
on comparisons between countries using subjective factors such as connections between entrepreneurship and social context; institutional support and innovation (Valliere 2019) reporting differences in performance, although reports such as GEM uses same subjective factors. Research has identified individuals' capabilities to pursue entrepreneurial activities in a socially constructed context is a key factor in determining the entrepreneurial activity as individuals follow social cues that give their actions a meaning (Ogunsade and Obembe 2016). While these cues show the objective opportunities and resources are not enough to create an impactful entrepreneurial activity, cultural factors that creates subjective meaning for the entrepreneurs' actions also matters (Valliere 2019). Therefore, culture is idiosyncratic to their personal and individualistic understanding and experiences.

Overall the study makes the following contribution to the entrepreneurship literature: previous research has examined the role of culture in terms of cognitive and behavioural aspects to determine the characteristics of the entrepreneur. In this paper, culture is viewed as an active construct that entrepreneurs understand and experience through socially dependent interrelationships. It is through this approach that the argument around culture is extended. First, it presents entrepreneurs' social capability as an important determinant of their ability to utilise their knowledge and experience of cultural factors, in their environment, to seek self-determination, belonging and identity. Second, entrepreneurs utilise their knowledge and experience of culture to seek social integration and acceptance in the market to achieve economic value. Therefore, in the cultural context of Jordan, entrepreneurs' understanding and knowledge of the value of the cultural factor is demonstrated by focusing on the national culture which is defined as a culture of collectivism, that is influenced by traditional ego culture; culture of shame and parental traditions and values (Alawamleh, et al. 2019).

\section{Theoretical Background:}

In understanding the impact of entrepreneurship on the economy, the Global Entrepreneurship Monitor (GEM) have used set of subjective factors as a comparison tool between countries to monitor entrepreneurship for development (Sautet 2013). These factors addressed national environmental and institutional conditions without much attention to individual level factors (Acs, Desai and Hessels 2008). It is already established that entrepreneurship contribute to economic growth and it is plays an important role in innovation and employment (Acs and Audretsch 2014; Baumol 2002). Yet these relations have been difficult to prove in developing countries despite national level efforts in capturing the role of entrepreneurship and economic development (Naude 2009; Sautet 2013). Using GEM report data Sautet (2013) found that this difficulty can be attributed to the nature of enterprises in developing country; for example necessity entrepreneurship is higher in developing countries than 
developed countries. This combined with low survival rate makes their contribution to development and economic growth negligible. While researchers have examined these relations from an economic point of view, looking at the role of institutions and ecosystems (Acs et al 2014; Baumol 2002); individual factors were overlooked in these studies. Social and cultural factors play a significant role in supporting entrepreneurship in developing economies; specifically, family and network connections. Entrepreneurs are socially embedded in networks as Casson (2010, p. 121) explain: "It is difficult, for example to communicate with someone who does not speak the same language or share the same beliefs or who cannot be trusted". These factors play a significant role in the entrepreneurs' journey specifically in the culture of collectivism (Cochran 1965) where strong family and social influences affect every decision made (Alawameleh et al. 2019). Therefore, a better understanding of how entrepreneurs deal with these factors is needed.

To capture the contextualisation of the factor, phenomenography as an interpretive qualitative methodology is used for this study. It enables a framing of the research to explore how entrepreneurs in Jordan, a developing economy, contextualise the inter-relationships between cultural factors. As such, entrepreneurs articulate the different understandings for their activity and of culture as a context (Brannback and Carsrud 2016). This study contributes to research by extending the understanding of the subjective role of culture as a context. Previous research approaches have predominantly used a dualist ontology, which stipulates that the person and the world are two separate entities; and an objectivist epistemology which assumes that there is a knowable reality beyond the human mind (Lamb, Sandberg and Liesch 2011). While research using rationalistic approaches introduced new context-related constructs, it also dropped others, by focusing on the situational and temporal contingencies through which a certain context becomes the focal point of research without much attention to the patterns around them (Bamberger 2015). A shift in research perspective is needed to extend our understanding. Therefore, using cognitive processes through which entrepreneurs articulate culture as a context through language and conversations (Brännback and Carsrud 2016; Steyaert and Katz 2004) is timely in this research. This shift brings the focus to the entrepreneurs' understanding and experiences, recognising the entrepreneurial skills, knowledge and experiences through which they contextualise their activity (Sarasvathy 2001; Welter 2011; Welter et al. 2018). Alongside research on culture and its role as a context, a growing number of researchers are calling for an interpretivist approach as an alternative to understand the role of the individual (Foss and Klein 2017; Garud, Gehman and Giuliani 2014; Packard 2017).

Furthermore, research on culture has presented the role of context and contextualisation, investigating culture as a factor and on most cases as a backdrop to the entrepreneurial activity (see Garud et al. 
2014; Welter et al. 2018); failing to capture the entrepreneurs' own narratives and interactions that explains why some entrepreneurs are innovative and thrive more than others. While researchers agreed that entrepreneurship is an individualistic venture, through which entrepreneurs are motivated to follow their vision and ambitions, and are prepared to reorganize their social environment accordingly, still the relation between certain cultural and societal factors to the initiation of entrepreneurship is insufficiently emphasised (Morrison 2000). As a result, these researches have presented conflicting results and called for further understanding of cultural diversity, examining culture in a new setting (Bamberger 2015; Welter et al. 2018) where culture plays a significant role in everyday life and in the entrepreneurs' own decisions about their career choices; which explains the efforts entrepreneurs invest in creating linkages across social elements that prompt their actions (Garud and Gehman 2016). Much of research on entrepreneurship culture has focused too myopically on individuals, teams and ventures (Autio et al. 2014; Davidsson 2006; Phan 2004). Although these studies have advanced the field of research, there are still some inadequacies in the existing explanations along with calls to capture culture in a new context through narratives (Garud and Gehman 2016; Bamberger 20015; Welter et al. 2018). This study addresses these issues by focusing on the variation in patterns and the different dynamics and relationships presented by entrepreneurial social behaviours.

\section{The National Context:}

The national context of this study is Jordan, a developing country in the Middle East. The culture in Jordan has been identified as an Arab-Islamic culture that envelopes three aspects: ego culture; a culture of shame or taboo and the parental traditions and values which stem from the tribal origins of the country (see Al-Awamleh et al. 2019; Caputo et al. 2016). Given that the Middle East in general suffers from high unemployment, especially youth unemployment, the region can benefit from entrepreneurial activity to boost its economy (OECD 2016; Malik and Awadallah 2013; World Bank 2017). Previous studies on the cultural context in Jordan have focused mainly on the role of culture from a gender perspective focusing on women entrepreneurs (Al-Dajani and Marlow 2013; GEM 2014). Furthermore, the role of cultural values toward e-commerce intentions in Jordan (Kahttab and Qutaishat 2012), have argued that the e-entrepreneurship may be a way of overcoming some of the traditional cultural beliefs in the Arab countries (Sidani 2005; Qasim et al. 2018) specifically in relation to women employment (Omet, Shami, Beino, Khalaf 2015). Nonetheless, these are clearly some of the barriers, since the GEM report (2014) have identified that the opportunity recognition in Jordan is high, entrepreneurial activity is among the lowest in the region. Jordan has few natural resources and a small industrial sector in addition to an economy that is reliant on foreign aid as well as tourism; this has positioned the government as the largest single employer in Jordan (Schiff, Schmidt and Troncoso 2015). Furthermore, the role of cultural values toward e-commerce intentions in Jordan (Kahttab and 
Qutaishat 2012), have argued that e-entrepreneurship may be a way of overcoming some of the traditional cultural beliefs in the Arab countries (Qasim et al. 2018; Sidani 2005) specifically in relation to women employment. Nonetheless, there are clearly barriers, since the GEM report (2014) has identified that while opportunity recognition in Jordan is high, entrepreneurial activity is among the lowest in the region. Further research seeking to understand how entrepreneurs contextualise the cultural factors is timely, especially given that entrepreneurship has been recognised as one of the country's priorities, and its development is backed by government support (Caputo et al. 2016; World Bank 2017). Jordan has a young, well-educated and dynamic population that is embarking on entrepreneurial activity, especially following the recent boom in the information communication technology (ICT) sector (Ameen et al., 2018), and the increasing encouragement of entrepreneurship as a means to address issues of high unemployment in the country (Caputo et al. 2016). Researchers have provided policy level recommendations to facilitate entrepreneurship through: competition policy, access to finance and entrepreneurial education; alongside improvements to economic governance in addition to training and skills development; in order to create jobs and employment opportunities (see Al-Shaik 2013; Mahmalat and Sumpf 2020). While some policy level measures have been implemented through the increase in entrepreneurship courses, educational and training programmes in universities (Eid 2007); the results of these programmes showed less significant influence in encouraging entrepreneurship due to cultural factors (Ayasrah, Obeidat, and Khatatbeh 2019; Eid 2007); contrary to entrepreneurship education programmes in developed countries reporting more positive outcomes (Katz 2002; Robinson and Haynes 1991). Therefore, it is important to understand what role, does the culture play in influencing the entrepreneurship activity in Jordan.

\section{Research approach and methodology:}

The research approach is an abductive approach (Peirce et al. 1958), through which the development of theoretical ideas will emerge using an iterative, interpretive approach. Themes emerged through structures of awareness producing categories of description (Marton 1981) using phenomenography as a methodology to capture the lived experiences of the entrepreneurs. Phenomenography is designed to capture how people understand a specific aspect of reality. It stipulates that individuals and their world are intertwined through their lived experience of the world (Husserl 1970). Therefore, the world is an experienced world and the human reality is socially constructed through individuals, understandings, experiences and actions (Berger and Luckmann 1991). Based on this premise, phenomenography, a qualitative approach, will be used to capture the variation in the different ways people understand the same aspect of reality; as "understanding" forms the basis of their actions (Lamb et al. 2011; Marton and Pong 2005; Sandberg 2005) these understandings relate their actions to the 
context they operate within and the culture they deal with. Therefore, through their narratives we capture how they contextualise the culture. By contextualising we mean "including the proper context and the persons fitting into that context" (Mey 2003: p.343). In this study, how entrepreneurs understand and deal with cultural factors in Jordan is the context of the study.

\section{Sample and Data Collection:}

In phenomenography, the main question of "who" to select for interview is important in order to capture the variation in experiences (Reed 2006). In this study, the sample of entrepreneurs was selected from different business incubators in Jordan with the variation in the start-up phases, i.e. there were participants at the nascent stage of their activity and others at the growth and scale up stages. According to Reed (2006; p.5) "a typical phenomenographical study would first have people perform a task or engage in some activity". This was achieved through finding a group of people for whom the research question would have a significant meaning (Flick 2009; Smith and Osborn 2003; Welman and Kruger 1999). The selected interviewees met the requirement of being "good informants" (Flick 2009), in that they had the necessary knowledge and experience of the phenomena in discussion, they could answer the questions and they were interested in taking part in the study (Flick 2009; Morse 1998). While the sample size of a qualitative enquiry is not defined by its size but rather by the purpose of the enquiry (Kvale 1996; Patton, 1990). The final sample of 25 entrepreneurs was interviewed. After the $24^{\text {th }}$ interview, we felt that we have achieved the theoretical saturation (Glaser and Strauss 1967). This is consistent with previous phenomenographic studies that suggest a sample of 20 participants is needed to capture maximum variation (Lamb et al. 2011; Sandberg 2000).

The primary data was gathered through in-depth interviews, supplemented by ongoing commentaries and information on the field of entrepreneurship through different reports and studies available. Phenomenographic interviews differ from other interviews as they are specifically designed to capture the variation in individuals understanding of their realties by focusing on utterances themselves and the interpretation made in relation to the context from which the utterance is taken (Akerlind 2005). Through this process, the phenomenon in question is identified and interpreted in terms of selected quotes from the interview by searching for variation in meaning across interview transcripts (Akerlind 2005). The interviews were open and guided by the questions, it follows a dialogue format to assist the entrepreneurs' narratives to be unrestricted and to provide a rich data that captures understanding and practice (Trigwell 2000). At the completion of the data collection phase, a total of 25 entrepreneurs have participated out of a pool of 30 , with 24 being interviewed. One did not participate in the 
interview process but rather answered the questions sent them by email. This did not conform with the research protocol, and the participant was discounted from the final analysis.

\section{<insert Table 1 here>}

Several steps were taken in preparation for the interviews including: sending out introductory emails explaining the research focus and purpose and agreeing on a place and time for interview. The schedule of interviews varied with some days being busier than others and the length of interviews varied as well. At the start of each interview the format of the interview was explained, i.e. that this is a semi-structured interview revolving around their understanding and experiences of the cultural factors and that there are no right or wrong answers. This was important to make them more

comfortable in expressing their views. Recording interviews enhances the validity of the data by enabling a full and accurate record of the interview. It also provided an opportunity, to be "...free to be an attentive and thoughtful listener" (Minichiello et al., 1995: 98), this also enabled us to probe the responses provided further if necessary. Each interview lasted between 40-80 minutes. A journal of reflections after each interview was kept, in which unspoken experiences were recorded and impression of the interviewee. The interview question was presented "how do you understand the cultural factors and how do you deal with them?" several probing questions were introduced such as what does culture mean to you? How do you experience it? These questions were asked to establish a communicable understanding and to capture the first hand understanding through their definitions. Then we tried to capture the deeper meaning by asking about their understanding and lived experience of culture as context in relation to their activity. During each interview the intention was to remain an observer in the background, so as to allow each participant to elaborate and express their understanding without interference or interruption (Minichiello et al., 1995; Rubin and Rubin, 1995).

\section{Data Analysis}

Data analysis was guided by phenomenographic procedures as explained by Marton and Booth (1997) and Cope (2011); in addition to reflexivity (Alvesson 2003). The procedure followed a rigorous interpretive and iterative practice between what cultural factors entrepreneurs deal with; capturing the variation in understanding of the different factors; and how it affects their activity; capturing their experiences and actions. Although these seems like two different steps to capture the whole world of the entrepreneurs and their understanding and experiences as one entity with their world. A further focus on the "what" and "how" was given, to form the categories of description focusing on the statements in relation to the context of other statements and the transcript as a whole to glean the meaning out, rather than focusing on the frequency of each statement. For example (SOE1) statement 
below, it suggests the understanding of belonging to a community. This was expressed by other entrepreneurs being part of the business incubator provided that feeling.

“... when I deal with our own community, our community is booming, and it is a small community ... I see that there is a level of understanding and that makes me comfortable"

Taking this statement and reference it to its immediate context:

"if they (family) were more understanding, more engaging, more communicating with me, I would have made it in a shorter time instead of spending six miserable years"

The meaning is that entrepreneurs have different experiences, the look into the entrepreneurs community to support their identity and self-efficacy. They seek support due to the negative attitudes towards entrepreneurs. Their experience goes beyond the activity to capture the sense of belonging. We further tested and clarified the meaning of "Entrepreneurs' identity" in the above statement by linking them to other statements. This was supported by another statement from

“... lack of respect to the others, which is one of the most important things that hinders the entrepreneur." (MAME23)

The understanding is about the sense of belonging, the experience presents the lack of respect that they endure to their choice of becoming entrepreneurs. We interpreted these statements in relation to their immediate and external contexts. We did the same process for the next themes and as a result the understandings and experiences have emerged. This process continued until strong interpretations of the entrepreneurs understanding of culture were achieved. This process of checking and crosschecking provided for a more connected categories of descriptions to the role of culture presented two understandings and eight ways entrepreneurs experience culture in their environment. This process was repeated independently for all participants. We shifted the analysis from individual participants to comparing the understandings within and between groups. The final step was considering the what culture means and how they deal with it to present these understanding and experiences as a relational whole. The idea was to focus on the overall meaning of culture in relation to the entrepreneurial activity within the context of the country.

\section{Soundness of Method:}

The purpose of this study is to capture the variation in "understanding" of culture, and what that means to the entrepreneur, as an interpretive approach to the entrepreneurial culture as a context. Phenomenography as an interpretive methodology stipulates that the world is always an "understood" world (Sandberg 1994). Therefore it is purposively designed to capture how individuals and groups understand a specific reality, i.e, what it means to them and how that understanding forms the basis of their actions in specific to capture the variation in the qualitatively ways people understand the same aspect of reality as the basis for their practices (Marton and Pong 2005; Sandberg 2005). According 
to Sandberg (2000: 12) "understanding" refers to "people's ways of experiencing and making sense of their world". It refers to what something means to an individual, as it is through "understandings of reality decisions are made, individual make judgements and develop feeling and emotions (Deetz 2003). It represents people's ongoing experiences and relations with their world through which people make decisions and judgements about courses of action (Lamb 2011; Sandberg and Targama 2007). Capturing "understanding" as the basis of decision-making has been proven empirically in various interpretive studies (see Holt \& Sandberg 2011; Sandberg and Targama 2007).

The process of analysis required several attempts at reading and re-reading the transcripts (Miles and Huberman, 2014). It was important to take a second-order perspective during this process and to bracket away any personal views and understanding so not to influence the analysis. Each interview transcript was read several times in order to ensure that it captured the entrepreneurs' own understanding (Marton and Pong 2005; Sandberg 2000). The structure of awareness was revealed through identification of "what" cultural factors they deal with and "how" it affects their activity (Holt and Sandberg 2011). Through this lengthy process, a hierarchy of understanding emerged that captured the relationships between the different meanings and introduced an insight into the entrepreneurs' own world. The process included several phases of cross-checking to make sure that each understanding remained stable. Through the process of interpreting and analysing each group of transcripts, to present concise and connected categories of description (Cope 2004; Marton and Booth 1997). The findings were confirmed with the participants to make sure that the meanings they expressed during the interview were captured. The objective of this research is to capture the entrepreneurs' world as one; as a result, we introduce four qualitatively different understandings and eight experiences.

\section{Entrepreneurs' Contextualisation of Culture:}

Through phenomenography, the study has captured the understandings and experiences of entrepreneurs interactions with culture. This process presents their ability to contextualise these factors in relation to their activity. Four understandings and eight ways through which entrepreneurs have experienced culture is explained.

\section{Understandings 1: Entrepreneurs Social Capabilities:}

In this category the entrepreneurs' behaviours and experiences report an individualism behaviour, contrary to what the culture in Jordan is known for. Family and close friends are resisting the cultural change by emphasising the normative values of finding a job and not taking risk. Entrepreneurship is a foreign concept and it is not gaining acceptance. Therefore, entrepreneurs feel isolated and not 
understood by family and close network, they seek to find sense of community within the business incubator among other entrepreneurs, this provided them with a sense of actualisation. The family is not taking the entrepreneurship activity seriously and this is clearly explained by the entrepreneurs' experiences. Risk taking is not encouraged, therefore, fear of failure is another reason why families discourage entrepreneurship, it relates to the culture of employment and being risk averse, as part of the conditioning culture in Jordan.

Understanding 2: Entrepreneurs Identity and Self-efficacy: Entrepreneurs feel lack of respect and acceptance to what they are doing. On the other hand, we find women entrepreneurs are encouraged to start their own business, women report more positive experiences than men in this category. Overall, despite these negative experiences, entrepreneurs intentions are not compromised, entrepreneurs carry out with their activity and intention of being entrepreneurs. While the next category explains more complex ways in which entrepreneurs experience culture in relation to market culture and demands; these categories are inclusive and build on each other.

The above two categories present the cultural change from collectivism influenced by the family and social networks into an individualism culture. Through this finding we report a change in culture in Jordan. In this context, the negative culture did not affect the entrepreneurial intentions, which is different from previous research findings.

Understandings 3: Entrepreneurial confidence as a local start up: for this group of entrepreneurs experiences are about meeting and overcoming the clients perceptions towards them as a new and local business. Entrepreneurs experience with this understanding is to make concessions by providing extra services, reducing prices or even giving away product for trial for free until they build the relation with the market and introduce their products into the market. As a new business the challenge is not only breaking into the market but also to overcome the perceptions towards them being a local enterprise which reflects lack of trust in the local businesses. This builds on the risk-taking propensity in the society which affects the trust in small and new business; people prefer well known big companies that they trust. In the context of the country Jordan, this reflect the collectivist culture being risk averse and not taking entrepreneurship seriously. Clients reflect the same sentiment as families by not accepting entrepreneurship and not taking entrepreneurs seriously. Hence, the attempt to drive prices down with the comment "you are local company" and therefore the price has to be cheaper. These experiences have affected the entrepreneurs' confidence especially when competing with international companies. Clients' perceptions of local companies reflect the culture of the country in terms of their confidence in local providers and products, yet we see entrepreneurs willing to offer reduced prices 
and a long trial period for their products and services to gain trust. Despite these challenges entrepreneurs in this category exhibit determination to gain market share and continue their activity.

Understanding 4: Knowledge of Social and market values: for this group of entrepreneurs their knowledge of the market opportunities is clear, although they use the culture and the local values to their advantage by producing products and providing services within these values. They also, know that staying within these values can been limiting for their creativity and ability to explore other sectors. Placing this understanding in the context of the country and the region, we find that clients' expectations are also following the collectivist culture that stems from family and society's expectations and values. Entrepreneurs are conforming to these normative values to gain market share and client trust. Entrepreneurs use their knowledge and experiences as a competitive advantage to meet specific market needs and look for other markets to expand their activity into other sectors where the culture is not as restricting.

<insert table 2 here>

These understandings are inclusive and build on each other. Entrepreneurs express their knowledge of the market and clients' cultural values and how they deal with it to determine their market strategy and ability to compete in the local or regional markets. Despite the challenges of the cultural factors present in their environment the findings report that entrepreneurs' intentions to carry out their activity have not changed. Their ability to use social and cultural factors to create economic value is evident through the different strategies they use to gain trust and exhibit self-determination.

\section{Hierarchy of Entrepreneurs' Contextualisation of Cultural factors}

These findings reveal variations in understanding and experiences through which entrepreneurs contextualise cultural factors. Through our analysis, we identified four different ways entrepreneurs understand the context of culture and eight ways they experience it through their activities. These understandings are inclusive of each other and build on each other. The table captures the variations in understanding and experiences of the role of culture in the entrepreneurial activity in Jordan.

\section{<insert Table 2 here>}

The sample is male dominated, although females were represented ( 7 out of 25$)$. Gender did not seem to be related significantly to differences in understanding and defining their context, although female entrepreneurs felt more positive about their career choice to be an entrepreneur than male entrepreneurs. The variation was more evident among the entrepreneurs at a more advanced stage of 
their start-up, than those in early stages, since the former expressed more complex understandings and experiences. This can be due to having more knowledge and experience. The two early stage startups (one male and one female) are the two who reported the same challenges in respect of accessing markets and building trust with clients.

\section{A model of entrepreneurs' contextualisation of cultural factors:}

In this study on contextualisation of culture in entrepreneurship through an interpretive philosophical approach the researchers identify culture as the key determinant of entrepreneurial behaviour. The emergent categories of description present understandings and experiences of cultural factors. These understandings and experiences relate to the causal factors that influence their intentionality, identity formation and the process of social capability and integration (Packard 2017). The categories present themes that capture the entrepreneurs contextualisation of culture through their knowledge and understanding. Placing these understandings and experiences in context of the local culture of Jordan, the findings present four main understandings:

Understanding 1: Entrepreneurs' social capability: in this category the findings report entrepreneurs ability to influence the culture from collectivist to individualist orientation. This change has influenced the role of culture on the entrepreneurs intentions of becoming entrepreneurs and towards their activity. We report that entrepreneurs intentions has not changed despite the negative influence from families and close networks towards their activity.

Understanding 2: Entrepreneurs Identity and Self-efficacy: This category captures entrepreneurs struggle with respect and their fear of failure and accepting entrepreneurship as a career choice also challenge the normative culture of collectivism in Jordan. Despite this challenge we find entrepreneurs showing determination towards their career choice. Yet women experience a more positive support to their career choice as entrepreneur.

Understandings 3: Entrepreneurial confidence as a local start up: in this category the finding reports the clients' influence on the entrepreneurial identity and their attitudes towards local products and services. The findings report lack of trust in the local products and services through which entrepreneurs are lowering their prices and giving their services for free on a trial bases to gain trust. This also reflects entrepreneurs' experiences of the culture of collectivism that does not encourage risk taking. Although this has affected entrepreneurs' experiences and confidence as a local provider it did not affect their intention in carrying out their activity. 
Understanding 4: Knowledge of social and market values: This understanding has captured the overall knowledge of the market and clients' values and entrepreneurs' experience in meeting these values and staying within the clients' expectations of which sector entrepreneurs work within. Entrepreneurs' knowledge has an advantage but also can be restricting. Taking this category in the context of the country and the region, the findings report a culture of collectivism that forces entrepreneurs to stay within social and cultural values. In this category this knowledge is used to create economic value by meeting the clients' needs.

\section{<insert Figure 1 here>}

These understandings and experiences suggest an interrelated, dynamic relationship between entrepreneurial social capability, ability to integrate and the ability to create economic value.

\section{Discussion:}

This study addresses the role of culture and how entrepreneurs contextualise these factors within their environment. Contextualisation is intended to convey how entrepreneurs deal with the context within which they experience and understand these factors. This study introduced the individual level understanding and experiences, and how the entrepreneur uses these understandings to achieve personal goals and to deal with challenges presented by their environment. In the context of Jordan, the findings report that despite the policy level support toward entrepreneurship, cultural challenges at the family and social network level were evident. This finding supports the important role of trust, beliefs (Cochran 1965) and social networks in influencing the entrepreneurial activity in developing countries (Casson 2010; Sautert 2013). The findings report on how policy level encouragement can influence culture change. In this study due to policy level encouragement, entrepreneurs are influencing and driving a cultural change from collectivism to individualism, by carrying out their activity despite the family and networks challenges. The findings report differences in cultural factors between developed and developing countries and contribute to research argument that the role of culture cannot be generalised (Desai 2009; Dodds and Patra 2002). The findings present the cultural challenges facing entrepreneurial intention, identity and innovativeness in Jordan specifically towards women entrepreneurs whereas women report more positive experience; this may be due to the type of activity being e-entrepreneurship which the culture in Jordan encourages (Omet, Shami, Beino, Khalaf 2015). This study captures the challenges entrepreneurs in Jordan, a developing country with a conservative culture (Alawamleh 2019) deal with. The challenges present the policy level influence on driving cultural change within the family and social network, the influence on the clients and market 
culture has not changed and poses a restriction the entrepreneurial activity. We report on the different ways' entrepreneurs understand and experience these challenges as following:

Understanding 1: Entrepreneurial social capabilities: our findings report a change in the collective culture and family influence into an individualistic culture where entrepreneurs challenge the family influence and pursue their intentions of becoming entrepreneurs, despite experiencing lack of respect, fear of failure and feeling different. These experiences have emphasised their social isolation; yet they utilise their experience and understanding by calling for a change in thinking, asking to meet other entrepreneurs who failed so that they can learn from their experience. Our findings also reflect that despite the economic challenge in Jordan including high unemployment families still prefer employment over entrepreneurship as a career choice enforcing the collectivism values and social preference. Entrepreneurs are faced with social isolation, yet they use their knowledge and skills to achieve belonging and self-determination by connecting with other entrepreneurs. They find sense of belonging in the business incubator among a community of entrepreneurs. The business incubator is not only a business place but also has a role in creating a community for entrepreneurs to achieve selfactualisation and belonging to the entrepreneurs. In dealing with these changes and challenges, entrepreneurs have used their knowledge and their community of entrepreneurs in the business incubator to strengthen their identity, sense of belonging and to support their career choice. Entrepreneurs contextualise the cultural factors through their knowledge and experience to find purpose and self-determination through their need to connect to others and to belong and integrate (Deci and Ryan 1985).

Understanding 2: Entrepreneurial Identify and Self-efficacy: This finding highlights the importance of individualistic culture in promoting entrepreneurship, therefore, the finding reports the change in culture at the individual level and not the family and society level. This change reflects the entrepreneurs' determination in pursuing their activity despite the negative attitudes from family. Previous research reported that individualistic societies are more inventive than hierarchical societies (Davidsson and Wiklund 1997). And while our findings support the view that entrepreneurship is individualistic in nature, in the context of Jordan, entrepreneurs actively influence and challenge the collectivist culture in order to pursue their activity. Furthermore, the findings report that despite the negative culture at the family and social network level, entrepreneurs intentions were not affected. This is contrary to what previous research has reported (Klyver, Hindle and Meyer 2008).

Understanding 3: Entrepreneurial confidence as a local start-up: entrepreneurs' experiences with clients reflect two aspects of the culture in Jordan: first, lack of trust in the local services and products. 
This can be due to these activities being novel and clients being cautious in dealing with new start ups which reflects risk averseness propensities in Jordan, we would ordinarily associate with a collectivist culture. Second; the value of the local product and service is low. Clients expect local products and services to be cheaper. Entrepreneurs' experiences with their clients have been negative. They feel that a local start-up is a disadvantage. This is used by clients as a negotiation point to drive prices down and asking for more services for less; which left entrepreneurs with no choice but to make concessions in order to build trust and gain market share. In this category, we can link the entrepreneurial intention and confidence as two categories that relate to each other and that reflect family and social interactions in Jordan. Entrepreneurs in their interactions with family and clients find their identity, intentions and confidence challenged, yet they exhibit self-efficacy and determination by pursing their activity.

Understanding 4: Knowledge of Social and Market values: Entrepreneurs' knowledge of social values of the market is a competitive advantage to meet the market and client demands for certain products. Although entrepreneurs know of various demands; based on their knowledge of these markets, but the fact that they are from the same culture and share the same values they are being restricted to certain sectors. These restrictions are limiting their creativity and expansion plans. This understanding builds on the previous experiences of the culture of collectivism that goes beyond the national culture into the regional expectations and taboos. Entrepreneurs are aware of these expectations; they accept and comply with it to achieve the economic gains. Although they feel restricted by it, but they are willing to accept these restrictions to achieve the economic gain. This reflects the role of regional culture and its impact on innovation (Garud et al 2014), yet in this case it has a restrictive role. This finding addresses the calls to understand the relationship between cultural variation and entrepreneurship within a national setting (Fletcher and Selden 2016; Jones, Klapper, Rattan and Fayolle 2018).

These findings provide new insights to the role of culture as context and addresses several calls as following: while research in social network theory focused on introducing culture as a monodimension that can be generalised (Kyvle et al. 2008). Culture is not the same to every person, it is subjective and idiosyncratic in nature hence the variation in experiences. The experiences affect identity and social linkages, in addition to its impact on the activity, entrepreneurs use their social capabilities, understanding and skills to find alternatives; they employ their own capital in a "do it yourself" manner (Williams 2004) to achieve the status they want. The under exploration of context and contextualisation of culture in previous research is evident, due to the general character of findings. 
Hence the importance to contextualise these factors and understand their implications in entrepreneurial activity (Welter et al. 2018).

Entrepreneurs deal with factors in their environment. Therefore, understanding the role of culture in market action (Foss and Klein 2012) and how individuals interact with situations, while simultaneously explaining how situations influence individuals (Baker and Powell 2016; Welter et al. 2018) is important to capture which factors influence them. This study demonstrates the important role of culture in relation to market action, dealing with clients and ability to understand that cultural factors and values play an important role. We present the entrepreneurs' ability to understand and contextualise these factors within their actions, build their activity around this knowledge and use it to their advantage.

Current explanations of the role of culture in entrepreneurship show that there are negative social and cultural values in respect to women entrepreneurs in the Middle East (Al-Dajani and Marlow 2013; Mehtap et al. 2016). This finding alsoreport changes in support towards women entrepreneurs. Further exploration is required to understand this factor, especially that the female contribution to the work force in Jordan is among the lowest in the region, rated at less than 14\% (Omet, Shami, Beino, Khalaf 2015). There has been substantial research on social networks (Aldrich 2007; Janssen 2001) which presented the relational and performative linkages. The social network argument was consistent with the generalisable role of culture even between different countries; and presented it as a sub-factor (Garud and Geham 2016). The findings in this study emphasise the idiosyncratic nature of culture specifically between developed and developing countries (Desai 2009) in terms of its influence on entrepreneurial activity; specifically, in relation to risk taking, one of the main challenges being a risk averse culture. We found that the business incubator provided social support to entrepreneurial identity and intention by introducing a new normative culture. Our findings are in line with entrepreneurs found support through the business incubator that helped validate their identity and support their survival (Mas-Verdu, Ribeiro Soriano, Roig Tierno 2014). Entrepreneurs intentions towards their activity is being challenged by family and social networks, yet despite the culture of collectivism in Jordan (Alawmleh et al. 2019), our findings report a change towards a culture of individualism where entrepreneurs challenge the normative culture and pursue their activity. The culture of collectivism did not influence the entrepreneurial intention in this context.

Cultural factors influence the entrepreneurial activity in terms of dealing with clients and markets. Some findings are consistent with previous research findings, in relation to entrepreneurs showing resilience in the face of challenges (Vahlne et al. 2017) and negative culture towards them and in confirming their entrepreneurial intentions. In relation to entrepreneurial opportunities, we find their knowledge of cultural values can a provide a competitive edge, on one hand, and restrict their 
creativity on the other; which conforms with the "dark side of culture" noted by Welter (2011, p 171). The role of informal cultural factors also known as the codes of conduct, beliefs and values (AlAwamleh et al. 2019), may have negative influence on entrepreneurial intentions and opportunities, yet we report resilience towards these negative influences and a change in culture from collectivism to individualism driven by entrepreneurs. Entrepreneurs challenge their family influence and pursue their activity to achieve economic value.

\section{Conclusion and Limitation:}

This study has investigated entrepreneurs' contextualisation of culture in a national setting using Jordan, a developing country as the field of research. The findings posit there to be different trajectories for entrepreneurs to take based on their understanding of their environment and important implications for how entrepreneurs are motivated in a highly conservative environment. The entrepreneurs' ability to contextualise culture through phenomenography offers a new explanation of its role, by introducing a variation in entrepreneurs' social capabilities and skills within a national setting.

The findings highlight the limitations of the field due to the rationalistic assumptions that have underpinned this field of research and focuses on the application of phenomenography as an interpretivist, methodology that furthered the understanding of how entrepreneurs contextualise culture and how they use their social capability to achieve social integration and economic value. In terms of practical contribution, the study introduces a policy level contribution by addressing the issue raised by the GEM report (2014), that despite high entrepreneurial opportunity identification in Jordan, the country has the lowest entrepreneurial activity in the region. Although the report pointed out issues in policy and institutional support the role of culture was not addressed.

Through phenomenography we introduced a model of contextualisation of culture, which presents the variation in the entrepreneurs' understanding and experience of their environment in Jordan. We addressed the calls to investigate the culture in a new setting and capture the variation where we would expect the same results using interpretive qualitative methodologies (Walter et al. 2018). We addressed some of the several calls to further investigate and understand the role of culture, how entrepreneurs contextualise it (Foss and Klein 2012; Garud et al. 2016; Zahra et al. 2014; Welter et al. 2018). Our research provides a fertile ground for further enquiries that pose questions such as "What other factors do entrepreneurs contextualise in their environment?" and "how are these factors 
contextualised?" Using an interpretive methodology has confirmed that entrepreneurship is a process and not an outcome (Foss and Klein 2012; Foss et al. 2019), therefore, understanding the role of culture in shaping this process - specifically how entrepreneurs contextualise cultural factors (Welter 2011). Further research on capturing "understanding" presents the complex forms of interactions and mechanism in the cognitive world of the entrepreneurs (Barandiaran et al. 2009; Brannback and Carsrud 2016). We encourage further research in the Middle-East region to examine the model and identify other factors that affect entrepreneurial behaviour, including the important developments with regard to women entrepreneurs. While Jordan has embarked on introducing policy level changes to support entrepreneurship, the findings report that the culture of collectivism is changing. This requires a longitudinal research to capture the change and its implication on entrepreneurial activity in Jordan and its impact on unemployment and economic value. 


\section{References:}

Acs, Z.J., Autio, E. and Szerb, L., 2014. National systems of entrepreneurship: Measurement issues and policy implications. Research Policy, Vol.43 no. 3, pp.476-494.

Akerlind, G., 2005. Phenomenographic methods: A case illustration. Doing developmental phenomenography, Vol.24 no. 4, pp.321-334

Alawamleh, M., Ismail, L.B., Aqeel, D. and Alawamleh, K.J., 2019. The bilateral relationship between human capital investment and innovation in Jordan. Journal of Innovation and Entrepreneurship, Vol.8 no.1, pp.1-17.

Al-Dajani, H. and Marlow, S. (2013), "Empowerment and entrepreneurship: a theoretical framework", International Journal of Entrepreneurial Behavior \& Research, Vol. 19 No. 5, pp.503-524.

Aldrich, H.E. and Kim, P.H., (2007). Small worlds, infinite possibilities? How social networks affect entrepreneurial team formation and search. Strategic Entrepreneurship Journal, Vol.1; no.1- 2, $147-165$.

Al-Maaitah, N., Daoud, Y. S. and Shanti, R. A. (2019) 'To What Extent Micro Lending Institution's Policy Help to Improve Income and Employment Prospects of Women Startups: Case Study from Jordan', Journal of Small Business and Entrepreneurship Development, Vol.7 no.1, pp.41-59.

Alvesson, M. \& Sandberg, J., (2011). Generating Research Questions Through Problematization. Academy of Management Review, Vol.36; no. 2, 247-271.

Ameen, N., Willis, R., and Shah, M.H. (2018). An examination of the gender gap in smartphone adoption and use in Arab countries: A cross-national study. Computers in Human Behavior, Vol. 89, pp.148-162.

Autio, E., George, G. \& Alexy, O., (2011). International Entrepreneurship and Capability Development-Qualitative Evidence and Future Research Directions. Entrepreneurship: Theory and Practice, Vol.35 no.1, 11-37.

Autio, E. and Acs Z., (2014). Entrepreneurial innovation: The importance of context. Research Policy, Vol.43 no. 7, 1097-1108.

Ayasrah, S.M., Obeidat, M.M. and Khatatbeh, Q., 2019. Role of Entrepreneurship Development on Dissemination of the Culture and Concept of Creativity. Journal of Entrepreneurship, Business and Economics, Vol.7 no.1, pp.42-63.

Barandiaran, X.E., Di Paolo, E. \& Rohde, M., (2009). Defining agency: Individuality, normativity, asymmetry, and spatio-temporality in action. Adaptive Behavior, Vol.17 no. 5, 367-386

Berger, P.L. and Luckmann, T., 1991. The social construction of reality: A treatise in the sociology of knowledge (No. 10). Penguin UK

Brännback, M. and Carsrud, A.L., 2016. Understanding entrepreneurial cognitions through the lenses of context. In A Research Agenda for Entrepreneurship and Context. Edward Elgar Publishing. 
Buda, R. and Elsayed-Elkhouly, S.M., 1998. Cultural differences between Arabs and Americans: Individualism-collectivism revisited. Journal of Cross-Cultural Psychology, Vol.29 no.3, pp.487492.

Caputo, A., Mehtap, S., Pellegrini, M.M. and Al-Refai, R., 2016. Supporting opportunities for female entrepreneurs in Jordan. International Journal of Entrepreneurship and Small Business, Vol.27 no.2/3, pp.384-409.

Cope, J., (2011). Entrepreneurial learning from failure: An interpretative phenomenological analysis. Journal of Business Venturing, Vol. 26 no.6, 604-623.

Crotty, M., 1998. Introduction: The research process. The foundations of social research: Meaning and perspective in the research process, Sage Publishing pp.1-17.

Dalpiaz, E., Rindova, V. and Ravasi, D., 2016. Combining logics to transform organizational agency: Blending industry and art at Alessi. Administrative Science Quarterly, Vol.61 no.3, pp.347-392.

Deci, E.L. and Ryan, R.M., 1985. The general causality orientations scale: Self-determination in personality. Journal of research in personality, Vol.19 no. 2, pp.109-134.

Deetz, S., 2003. Reclaiming the legacy of the linguistic turn. Organization, Vol.10 no.3, pp.421-429.

Desai, S., 2009. Measuring entrepreneurship in developing countries (Research Paper No. 2009/10). Finland: UNU-WIDER.

Dodd, S.D. \& Patra, E., (2002). National differences in entrepreneurial networking. Entrepreneurship \& Regional Development, Vol.14 no.2, 117-134.

EID, F., 2007. Promoting Entrepreneurship: What It Means, and What It Means for the Middle East and North Africa. $A B C D E$, p.219.

Fayolle, A. and Liñán, F., 2014. The future of research on entrepreneurial intentions. Journal of Business Research, Vol.67 no.5, pp.663-666.

Foss, N.J. \& Klein, P.G., (2012). Organizing entrepreneurial judgment: A new approach to the firm. Cambridge University Press.

Garud, R., Gehman, J. \& Giuliani, A.P., (2014). Contextualizing entrepreneurial innovation: A narrative perspective. Research Policy, Vol.43 no.7, 1177-1188.

Garud, R. \& Gehman, J., (2016). Theory evaluation, entrepreneurial processes, and performativity. Academy of Management Review, Vol.41 no.3, 544-549.

Hayton, J.C., George, G. \& Zahra, S.A., (2002). National culture and entrepreneurship: A review of behavioral research. Entrepreneurship theory and practice, Vol.26 no.4, 33-52.

Herrera-Echeverri, H., Haar, J. \& Estévez-Bretón, J.B., (2014). Foreign direct investment, institutional quality, economic freedom and entrepreneurship in emerging markets. Journal of Business Research, Vol.67 no.9, 1921-1932.

Hindle, K., (2010). How community context affects entrepreneurial process: A diagnostic framework. Entrepreneurship \& Regional Development, Vol.22 no.7-8, 599-647. 
Hmieleski, K.M. and Corbett, A.C., 2006. Proclivity for improvisation as a predictor of entrepreneurial intentions. Journal of Small Business Management, Vol.44 no. 1, pp.45-63.

Hofstede, G., 1980. Culture and organizations. International Studies of Management \& Organization, Vol.10 no.4, pp.15-41.

Holt, R., \& Sandberg, J. (2011). Phenomenology and organisation theory. In H. Tsoukas \& R. Chia (Eds), Philosophy and organisation theory. Oxford: Oxford University Press.

Husserl, E., (1970). The crisis of European sciences and transcendental phenomenology: An introduction to phenomenological philosophy. Northwestern University Press.

Global Entrepreneurship Monitor: GEM-MENA Regional Report 2009.

Jenssen, J.I., (2001). Social networks, resources and entrepreneurship. The International Journal of Entrepreneurship and Innovation, Vol.2 no.2, 103-109.

Jones, P., Klapper, R., Ratten, V. \& Fayolle, A., (2018). Emerging themes in entrepreneurial behaviours, identities and contexts. The International Journal of Entrepreneurship and Innovation, Vol.19 no.4, 233-236.

Kahttab, S.A., Al-Manasra, E.A., Zaid, M.K.S.A. and Qutaishat, F.T., 2012. Individualist, collectivist and gender moderated differences toward online purchase intentions in Jordan. International Business Research, Vol.5 no.8, p.85.

Katz, J.A., 2003. The chronology and intellectual trajectory of American entrepreneurship education: 1876-1999. Journal of business venturing, Vol.18 no.2, pp.283-300.

Klyver, K., Hindle, K. \& Meyer, D., (2008). Influence of social network structure on entrepreneurship participation-A study of 20 national cultures. International Entrepreneurship and Management Journal, Vol. 4 no.3, 331-347.

Kirkley, W.W., 2016. Entrepreneurial behaviour: the role of values. International Journal of Entrepreneurial Behavior \& Research, Vol. 22 no.3

Krueger Jr, N.F. and Day, M., 2010. Looking forward, looking backward: From entrepreneurial cognition to neuro entrepreneurship. In Handbook of entrepreneurship research (pp. 321-357). Springer, New York, NY.

Kvale, S., (1983). The qualitative research interview: A phenomenological and a hermeneutical mode of understanding. Journal of Phenomenological Psychology, Vol. 14 no.2, 171-196.

Lamb, P., Sandberg, J. \& Liesch, P.W., (2011). Small firm internationalisation unveiled through phenomenography. Journal of International Business Studies, Vol. 42 no.5, 672-693.

Liñán, F., Urbano, D. and Guerrero, M., 2011. Regional variations in entrepreneurial cognitions: Startup intentions of university students in Spain. Entrepreneurship and Regional Development, Vol. 23 no.3-4, pp.187-215. 
Lounsbury, M., Gehman, J. and Ann Glynn, M., 2019. Beyond homo entrepreneurus: Judgment and the theory of cultural entrepreneurship. Journal of Management Studies, Vol. 56 no.6, pp.12141236.

Lounsbury, M. and Glynn, M.A., 2001. Cultural entrepreneurship: Stories, legitimacy, and the acquisition of resources. Strategic management journal, Vol. 22 no.6- 7, pp.545-564.

Malik, A. and Awadallah, B., 2013. The economics of the Arab Spring. World Development, Vol. 45, pp.296-313.

Marton, F., 1981. Phenomenography-describing conceptions of the world around us. Instructional science, Vol.10 no.2, pp.177-200.

Marton, F. \& Ling, L.M., (2007). Learning from “The Learning Study.” Tidskrift för lärarutbildning och forskning, Vol.1 no.1, 31-44.

Marton, F., \& Pong, W. Y. (2005). On the unit of description in phenomenography. Higher Education Research and Development, Vol.24 no.4: 335-348.

Mas-Verdú, F., Ribeiro-Soriano, D. \& Roig-Tierno, N., (2015). Firm survival: The role of incubators and business characteristics. Journal of Business Research, Vol.68 no.4, 793-796.

Mey, J.L., 2003. Context and (dis) ambiguity: a pragmatic view. Journal of pragmatics, Vol.35 no.3, pp.331-347.

Morrison, A. (2006), "A contextualisation of entrepreneurship", International Journal of Entrepreneurial Behavior \& Research, Vol. 12 No. 4, pp. 192-209.

Naudé, W., 2010. Entrepreneurship, developing countries, and development economics: new approaches and insights. Small business economics, Vol.34 no.1, p.1

Ogunsade, I.A. and Obembe, D., 2016. The influence of informal institutions on informal sector entrepreneurship: a study of Nigeria's hand-woven textile industry. Journal of Small Business \& Entrepreneurship, Vol.28 no.6, pp.413-429.

Packard, M.D., 2017. Where did interpretivism go in the theory of entrepreneurship? Journal of Business Venturing, Vol.32 no.5, pp.536-549.

Peirce, C.S., 1958. Collected Papers: Science and philosophy and Reviews, correspondence, and bibliography (Vol. 7). Belknap Press of Harvard University Press.

Qasim, D., Mohammed, A.B. and Liñán, F., 2018. The role of culture and gender in e-commerce entrepreneurship: Three Jordanian Case studies. In Entrepreneurship Ecosystem in the Middle East and North Africa (MENA) (pp. 419-432). Springer, Cham.

Robinson, P. and Haynes, M., 1991. Entrepreneurship education in America's major universities. Entrepreneurship Theory and Practice, Vol.15 no.3, pp.41-52.

Sandberg, J., (2005). How Do We Justify Knowledge Produced Within Interpretive Approaches? Organizational Research Methods, Vol.8 no.1, 41-68. 
Sarasvathy, S.D., 2001. Causation and effectuation: Toward a theoretical shift from economic inevitability to entrepreneurial contingency. Academy of management Review, Vol.26 no.2, pp.243-263.

Sautet, F., 2013. Local and systemic entrepreneurship: Solving the puzzle of entrepreneurship and economic development. Entrepreneurship Theory and Practice, Vol.37 no.2, pp.387-402.

Shepherd, D. a. \& Patzelt, H., (2011). The New Field of Sustainable Entrepreneurship: Studying Entrepreneurial Action Linking "What Is to Be Sustained" With "What Is to Be Developed." Entrepreneurship Theory and Practice, Vol.35 no.1, 137-163.

Sidani, Y., 2005. Women, work, and Islam in Arab societies", Women in Management Review, Vol. 20 Issue: 7, pp.498-512,

Smith, J.A., 2003. Qualitative psychology: A practical guide to research methods. Sage Publications, Inc.

Steyaert, C. \& Katz, J., (2004). Reclaiming the space of entrepreneurship in society: geographical, discursive and social dimensions. Entrepreneurship \& Regional Development, Vol.16 no.3, 179196.

Swidler, A., 1986. Culture in action: Symbols and strategies. American sociological review, Vol. 51, no. 2, pp. 273-286

Walter, S.G. \& Dohse, D., (2012). Why mode and regional context matter for entrepreneurship education. Entrepreneurship \& Regional Development, Vol.24 no.9/10, p.807-835.

Weber, K. and Dacin, M.T., 2011. The cultural construction of organizational life: Introduction to the special issue. Organization Science, Vol.22 no.(2), pp.287-298.

Welter, F., Baker, T. \& Wirsching, K., (2019). Three waves and counting: the rising tide of contextualization in entrepreneurship research. Small Business Economics, Vol.52 no.(2), 319330 .

Welter, F., (2011). Contextualizing Entrepreneurship-Conceptual Challenges and Ways Forward. Entrepreneurship: Theory and Practice, Vol.35, pp.165-184.

Whetten, D.A., (2009). An Examination of the Interface between Context and Theory applied to the study of Chinese organizations. Management and Organization Review, Vol.5 no.1, pp.29-55.

World Bank Group, 2013. Global financial development report 2014: Financial inclusion (Vol. 2). World Bank Publications.

Valliere, D., 2019. Refining national culture and entrepreneurship: the role of subcultural variation. Journal of Global Entrepreneurship Research, Vol.9 no. 1, p.47.

Vahlne, J.E., Hamberg, M. \& Schweizer, R., (2017). Management under uncertainty-the unavoidable risk-taking. Multinational Business Review, Vol.25 no. 2, pp. 91-109.

Vuorio, A.M., Puumalainen, K. and Fellnhofer, K., 2018. Drivers of entrepreneurial intentions in sustainable entrepreneurship. International Journal of Entrepreneurial Behavior \& Research. Vol. 24 No. 2, 2018 pp. 359-381 
Zahra, S. a., Wright, M. \& Abdelgawad, S.G., (2014). Contextualization and the advancement of entrepreneurship research. International Small Business Journal, Vol.32, No. 1-22, pp. 479-500.

Zhao, E.Y., Fisher, G., Lounsbury, M. and Miller, D., 2017. Optimal distinctiveness: Broadening the interface between institutional theory and strategic management. Strategic Management Journal, Vol. 38 no. 1, pp.93-113. 
Table 1: Summary of Participants

\begin{tabular}{lll}
\hline \multicolumn{1}{l}{ Total number of Entrepreneurs in this study } & $\mathbf{2 5}$ \\
\hline Gender & Male & 18 \\
& Female & 7 \\
Age & Range of years & $28-49$ years \\
Level of Education & High school & 1 \\
& Undergraduate & 18 \\
& Postgraduate & 6 \\
Entrepreneurs interviewed & 24 & \\
Entrepreneurs dropped from sample & 1 & \\
\hline
\end{tabular}


Table 2: Entrepreneurs own understandings and experiences and sample of quotes

Understanding

Entrepreneurial Social Capabilities
Representative quotations

"... when I deal with our own community, our community is booming, and it is a small community ... I see that there is a level of understanding and that makes me comfortable" (SOE1)

"For me as an entrepreneur it means the ecosystem that I am having here, the ecosystem the interaction with other start-ups.” (ZBE2)

"My personal experiences are always negative because as an entrepreneur I am doing something different" (SOE1)

Identity and Self- "... when I graduated from the university my parents efficacy were waiting for me to stop working at the company, which I had been doing for five years, and start looking for a job within my field of study." (AMME3)

"For them this company that I have established doesn't have a future. This is an example of the societal values and culture that can either motivate or hinder the person."

"My family wasn't taking me seriously until my story was covered in the newspaper, I became the hero." (LHE16)

"Jordan is becoming amazing. In terms of support to become an entrepreneur, where the culture was ten years ago it was crazy for someone to leave a full-time job to start their own business" (EHE5)

"we need to have a paradigm shift ... for people to see it is not a major issue for a person to leave their work and start their business, even if they fail" (MIE15)

\section{Entrepreneurial confidence as a local start-up}

"it is not easy to deal with the local market because they look at you as a local company” (SQE6)

"So when I tell a client that I am willing to provide you with the solution, with best practices and consultation, they look at me "you are local" which affects our pricing." (MQE13)

"I am new in the market, with a new product, but people will not buy from me because I am new in the market" (SME7)
Experiences

Seeking belonging and acceptance

Seeking Respect

Support to women entrepreneurs

Fear of failure

Lower value

Lack of trust 
"I am the only one in the market that provides this product and services ... at the same time, I am unable to find a break in the market"

"I offer them the product for one year to try it for free, once they see what this product can do then I can have a client who can tell others that my solution works"

Knowledge of Social and Market values

"We understand many of these things; the things that are liked by the region and what is not liked ... it's one of our major competencies, like one of our major edges, is we know what people like and people don't like" (JSHE8)

"we notice that there is a big difference when we want to produce something for the Saudi market ... we were forbidden from some things ... such as $3 D$ female characters or even adding music ... We believe that these values can hold the creative people back" (IOE12)

"accessing talent and monetising that talent ... have lots of issues in Jordan. The creative industry is a different market and people still don't believe that it can be income generating." (MKHE9)

"as a regional person from Jordan and operation from Jordan and so on, we can't be working with a game that contains any sort of gambling ... it's like a taboo." (WRE18).
Knowledge of clients cultural needs

Culture is a competitive advantage 
Figure 1: Contextualisation of Culture

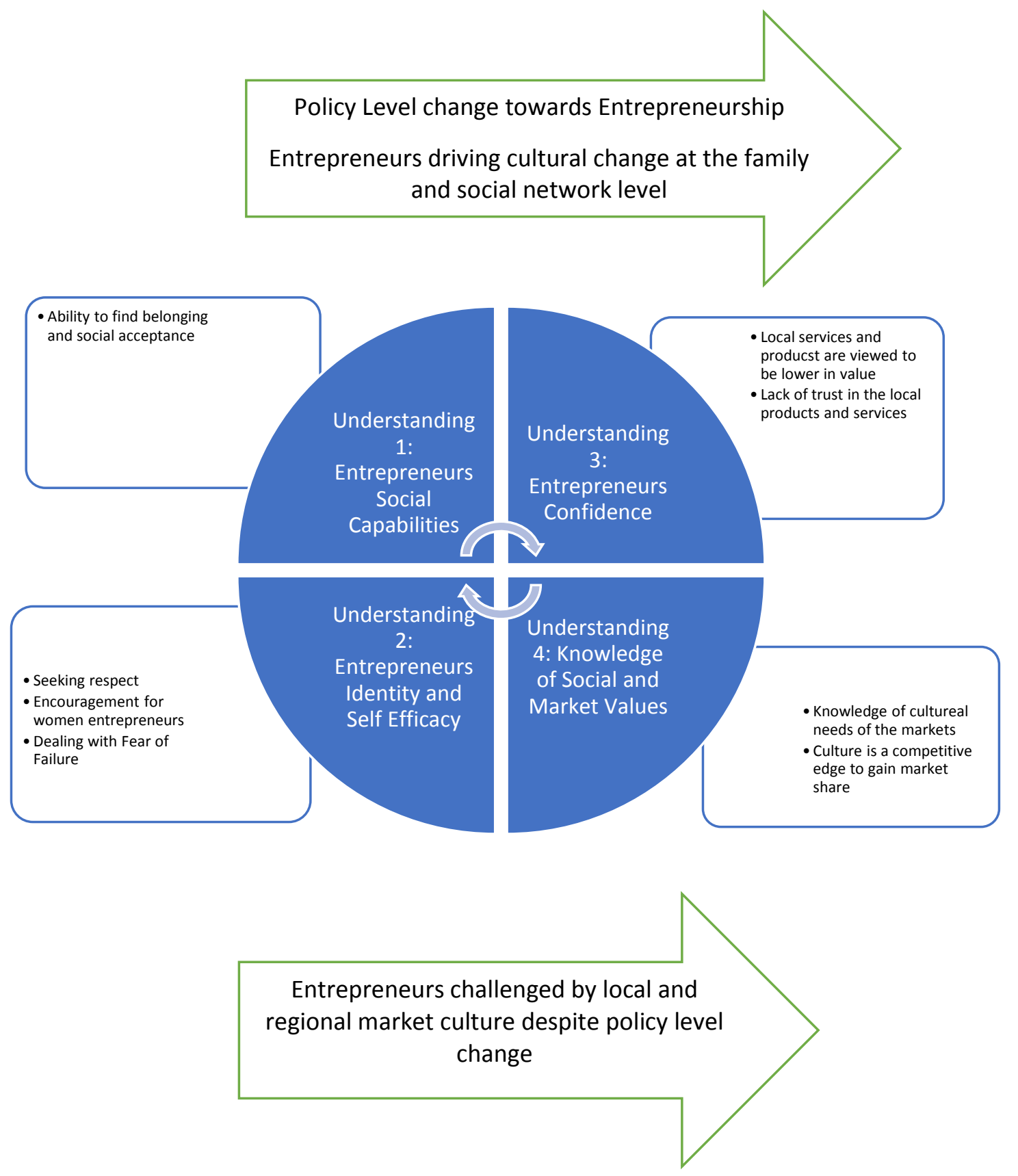


Table 3 Variation in Sample

\begin{tabular}{|c|c|c|c|c|}
\hline & $\begin{array}{l}\text { Entrepreneur } \\
\text { social } \\
\text { Capabilities }\end{array}$ & $\begin{array}{l}\text { Self-Efficacy and } \\
\text { Identity }\end{array}$ & $\begin{array}{l}\text { Entrepreneurs } \\
\text { Confidence }\end{array}$ & $\begin{array}{l}\text { Entrepreneurs } \\
\text { Knowledge of } \\
\text { social and market } \\
\text { values }\end{array}$ \\
\hline $\begin{array}{c}\text { Number of } \\
\text { Entrepreneurs }\end{array}$ & 4 & 4 & 7 & 5 \\
\hline $\begin{array}{c}\text { Gender: } \\
\text { Male }\end{array}$ & 3 & 3 & 6 & 4 \\
\hline Female & 1 & 1 & 1 & 2 \\
\hline $\begin{array}{c}\text { Start-up phase } \\
\text { Growth/Acceleration }\end{array}$ & 5 & 3 & 2 & 3 \\
\hline phase & 4 & & & \\
\hline
\end{tabular}

